\title{
Notes on Length-Weight Relationship and Condition Factor of Fresh Water Fish, Labeo boga (Hamilton) (Cypriniformes: Cyprinidae)
}

\author{
M.Rokshanara Pervin and M. Golam. Mortuza \\ Fisheries research Laboratory, Department of Zoology, Rajshahi University, \\ Rajshahi 6205, Bangladesh. \\ Key words: Labeo boga, length-weight relationship, condition factor
}

Labeo boga is a freshwater fish species commonly known as 'Bhangan bata' in Bangladesh. This freshwater fish is commonly found in streams, canals, beels, ponds and floodplains of Bangladesh (Rahman, 1989). Recently this fish is widely cultured throughout the Bangladesh.

The length-weight relationship is very important for proper exploitation and management of the population of fish species. To obtain the relationship between total length and other body weight are also very much essential for stabilizing the taxonomic characters of the species. Among the freshwater fishes, length-weight relationship of different fishes has been done by many researchers, viz., Tilapia mosambica (Dhoa \& Dewan, 1967), Puntius stigma (Islam \& Hossain, 1991-92), Alia coila (Alam et al., 1994), Chanda nama and Chanda ranga (Iqbal et al., 199596), Botia lohachata (Mortuza \& Mokarrama 2000), Rhinomugil corsula (Mortuza \& Tawfeequa, 2006).

The changes in weight in relation to length are generally not on the basis of specific gravity but due to changes in the form of volume because the density in the organism and that of the surrounding water. Such changes are analyzed by the condition factor or "Pondered index" (Le cren, 1951). The present work has been done on the morphometric aspects such as length-weight relationship and condition factor of $L$. boga.

A total of 550 specimens were collected for the morphometric analysis from different fish markets of Rajshahi city during the period of June 2006 to May 2007. The monthly collections were sexed and group in to respective size group (10 size group of $20 \mathrm{~mm}$ class intervals). The males were found to range from 91 to $286 \mathrm{~mm}$ in total length and total weight was ranged between 8 to $356 \mathrm{~g}$. In case of females, the total length and weight were ranged from 92 to $290 \mathrm{~mm}$ and 10 to 450 g respectively. The mean total length for male was calculated as $190.15 \pm 5.249 \mathrm{~mm}$ and the mean total weight calculated as106.387 $\pm 6.716 \mathrm{~g}(\mathrm{~N}=168)$. For female, the mean total length and weight were calculated as $195.8091 \pm 3.301 \mathrm{~mm}$ and $104.20 \pm 4.286 \mathrm{~g}$ $(\mathrm{N}=332)$ respectively.
The length-weight relationship calculated as:

$$
\begin{aligned}
& \log W=-73.60 \pm 1.001 \operatorname{logL}, r=0.877 \text { or } \\
& W=0.0004 \pm 0.5376 L \text { (male) } \\
& \log W=-195.31 \pm 1.576 \log \mathrm{L}, r=0.846 \text { or } \\
& W=0.0013 \pm 0.1559 \mathrm{~L} \text { (female) } \\
& \mathrm{Log} W=-144.98 \pm 1.313 \log \mathrm{L}, \mathrm{r}=0.853 \text { or } \\
& W=0.1242 \pm 0.5811 \mathrm{~L} \text { (unsexed) }
\end{aligned}
$$

Hile (1936) and Martin (1949) observed that the value of the regression coefficient ' $n$ ' usually lies between 2.5 to 4.0 and for ideal fish maintain the shape $\mathrm{n}=3$. The value of regression co-efficient is nearly equal for male (2.975) and slightly higher (3.289) in case of female and combined sexes (3.108.). The higher values of ' $n$ ' revealed that the length-weight relationships of this species followed the cube law and might be affected by the general condition of appetite and gonadal contents of fish. These factors are also responsible for the variation of condition factors and relative condition factors (Dhoa \& Dewan, 1967).

The condition factor $(\mathrm{K})$ was determined by two ways from observed values and from calculated values. For observed values in case of male it ranged from 0.831 to 2.687 with a mean as $2.1194 \pm 1.9586$. In female, it was ranged from 1.827 to1.568 with a mean as $1.1601 \pm 0.2537$. For unsexed specimens, it ranged from 0.916 to 1.468 with mean as $1.3241 \pm 1.1712$. The mean calculated condition factor $(\mathrm{K})$ was $2.7223 \pm$ 1.0829 with ranged of 1.543 to 4.214 in male, 0.352 to 4.263 with mean of $1.4436 \pm 1.0265$ for female. In case of combined males and females, the mean $\mathrm{K}$ was $1.4801 \pm 0.5647$ with a range of 0.423 to 2.895 .

The relative condition factor $(\mathrm{Kn})$ has been estimated by dividing the observed mean weight (TW) by the calculated weight TW. The Kn values ranged from 0.2232 to 1.8932 (male), 0.07991 to 1.4259 (females) and 0.14327 to 2.66784 (unsexed). The mean Kn was calculated as $1.050 \pm 0.5005,0.5555 \pm 0.3156$ and $0.8865 \pm 0.5647$ for males, females and combined sexes respectively. The value of $\mathrm{Kn}$ showed fluctuations between the sexes. It was may be due to several reason, such as feeding intensity, gravid condition of female or other factor (Shafi \& Quddus, 1974). 


\section{References}

Alam, M.R., M.G. Mortuza, S. Serajul Islam \& M.A. Hossain. 1994. Notes on size requency distribution and lengthweight relationship of freshwater fish Alia coila (Hamilton-Buchanan) (Siluriformes: Schilbeidae). Univ. J. $\quad$ Zool. Rajshahi Univ. 13: 69-70

Doha. S. \& Dewan, S. 1967. Studies on the biology of Tilapia, length weight relationship and condition factor. Pakistan J. Sci. 19:14-23.

Hile, R. 1936. Age and growth of cisco Leucichthys artedi le Suercur in the lakeo of north-earstern highland. $S$. Bull. US. Bur. Fish. 48:211-317.

Iqbal, M.S., Mortuza, M.G. Parween, S. \& M.A. Hossain. 1995-96. Length-weight relationship and condition factor of Chanda nama (Hamilton) and Chada ranga (Hamilton). Rajshahi Univ. Std. Part-B 23-24:237242.

Islam, M.S. \& Hossain, M.A. 1991-92. Length-weight relationship and condition factor of common punti, Puntius stigma ( Cuvier \& valenciennes ) (Cypriniformes: Cyprinidae). Univ. J. Zool. Rajshahi Univ. 10\&11: 109-110.
Le Cren, E.D. 1951. The length-weight relation ship and seasonal cycle in gonadal weight and codition in the perch. Perca fluviatilus. J. Anim. Ecol. 20: 201-219.

Martin, W.R. 1949. The machanics of environmental control of body form in fishes. Univ. Toronto. Stud. Biol. 58: 1-91.

Mortuza, M.G. \& Mokarrama, T. 2000. Length-weight relationship and condition factor of mud loach Botia lohachata (Chaudhuri) (Cypriniformes: Cobitidae Univ. J. Zool. Rajshahi Univ. 19: 113-114.

Mortuza, M.G. \& Tawfeequa, R. 2006. Length-weight relationship, condition factor and sex-ration of freshwater fish, Rhinomugil corsula (Hamilton) (Mugiliformes: Mugilidae) from Rajshahi, Bangladesh. J. bio-sci. 14: 139-141.

Rahman, A.K. 1989. Freshwater Fishes of Bangladesh. Zoological society of Bangladesh. 155p.

Shafi, M. \& Quddus, M. M. 1974. Length-weight relationship and condition factor in Hilsa ilisha (Hamilton) (Clupeiformes: Clupeidae). Bangladesh J. Zool. 2(2): 179-185.

Manuscript received on17.062008, accepted on 03.09 .2008 